\title{
PENGARUH TEKNIK CINEMA THERAPY DALAM BIMBINGAN KELOMPOK TERHADAP PERILAKU PROSSOIAL SISWA KELAS VIII SMP IHYAUSSALAFIYAH SURABAYA
}

\author{
Muhammad Hilmy Khoiri \\ Program Studi Bimbingan dan Konseling. Fakultas Keguruan dan Ilmu Pendidikan, \\ Universitas PGRI Adi Buana Surabaya \\ hilmykhoiri2@gmail.com
}

\author{
Boy Soedarmadji \\ Program Studi Bimbingan dan Konseling. Fakultas Keguruan dan Ilmu Pendidikan, \\ Universitas PGRI Adi Buana Surabaya \\ boyunipasby@gmail.com
}

\begin{abstract}
Abstrak
Prososial adalah salah satu sikap positif yang dapat menunjang kehidupan sosial serta akademik siswa di sekolah. Cinema Therapy sebagai salah satu teknik dalam bimbingan kelompok diasumsikan dapat meningkatkan prososial siswa dalam kehidupan sehari-hari. Metode penelitian yang digunakan adalah menggunakan desain penelitian One Group Pretes Postes Desaign, populasi 29 siswa kelas VIII SMP Ihyaussalafiyah Surabaya. Penelitian ini melibatkan 7 siswa kelas VIII sebagai sampel penelitian yang diambil secara purposive sampling. Tes validitas pengukuran skala butir siswa kontrol diri termasuk 0,393-0,780. Hasil uji reliabilitas Alfa Cronbach sebesar 0,937. Berdasarkan hasil penelitian, perhitungan diperoleh oleh Asymp. Sig = 0,017 Perbandingan Asymp. Sig $=0,017<\alpha=0,05$ maka H0 ditolak dan Ha diterima. Artinya ada pengaruh yang signifikan terhadap penggunaan teknik cinema therapydalam bimbingan kelompok terhadap perilaku prososial siswa kelas VIII SMP Ihyaussalafiyah Surabaya.

Kata Kunci: Prososial, Teknik Cinema Therapy, Bimbingan Kelompok
\end{abstract}

\begin{abstract}
Prosocial is one of the positive attitudes that can support students social and academic life in school. Cinema Therapy as one of the techniques in group guidance is assumed to be able to improve students prosocial activities in daily life. The research method used is using the research design of One Group Pretes Postes Desaign, the population of 29 students of class VIII junior high school Ihyaussalafiyah Surabaya. This study involves 7 students of class VIII as a sample of research taken by purposive sampling. Test the validity of grain scale measurement of self-control students include 0,393-0,780. Cronbach alpha reliability test results of 0.937. Based on the research result, the calculation was obtained by Asymp. Sig $=0.017$ Asymp Comparison. Sig $=0,017<\alpha=0,05$ then HO is rejected and Ha accepted. This means that there is significant influence on the use of Cinema therapy techniques in group guidance on the behavior of prosocial students VIII SMP Ihyaussalafiyah Surabaya.. Keywords: Prosocial, Cinema Therapy Techniques, Group Guidance
\end{abstract}




\section{LATAR BELAKANG}

Indonesia terkenal sebagai negara yang ramah penduduknya serta memiliki jiwa sosial yang tinggi. Saat melihat wisatawan asing diwawancarai oleh reporter Indonesia maka salah satu keunggulan negara ini yang akan mereka utarakan adalah bahwasanya penduduk Indonesia ramah, suka menolong dan murah senyum. Bertolak belakang dengan segala hal yang telah diutarakan di atas, akhir-akhir ini dapat dengan mudah kita jumpai sebuah kejadian yang sama sekali tidak sesuai dengan budaya ramah-tamah orang indonesia di negeri ibu pertiwi ini. Melihat media massa, anda akan dengan mudah menjumpai berita perpecahan NKRI, tawuran antar pelajar sampai konflik antar kelompok yang sedang terjadi saat ini.

Banyak kasus yang memperlihatkan karakter dan budaya ramah-tamah makhluk sosial yang dimiliki masyarakat indonesia telah terkisis secara perlahan dan mulai menjadikan perilaku anti-sosial menjadi lebih berkuasa. Lebih mirisnya lagi, kasus-kasus berikut ini adalah kasus yang dialami oleh para pelajar sebagai calon penerus bangsa nantinya. Hamidah (dalam Isnandar, 2010) bahkan menemukan bahwa di tujuh daerah di Jawa Timur menunjukkan adanya indikasi penurunan kepedulian sosial dan kepekaan pada remaja terhadap orang lain di lingkungannya. Paparan tersebut menunjukkan bahwa perlunya ditanamkan sebuah perilaku untuk dapat membuat para siswa mengerti dan menjalankan budaya sosial positif yang dimiliki oleh negara Indonesia, salah satunya adalah perilaku prososial yang bertolak belakang dengan anti-sosial. Prososial menurut Baron dan Branscombe (2012) dapat diartikan sebuah perilaku membantu orang lain tanpa harus menyediakan keuntungan pada orang yang melakukan pertolongan, terlepas apapun motif ataupun alasan si penolong tersebut pada saat melakukan bantuan.

Hal tersebut jelas akan menumbuhkan kebersamaan dan menciptakan lingkungan sosial belajar yang kondusif dan positif pula bagi para siswa di sekolah. Berhubungan dengan fenomena dewasa ini dimana mayoritas siswa memiliki gadget dan mengakses media sosial, sudah barang tentu mereka sangat akrab dengan streaming video/film baik itu di Facebook, Instagram, dan Youtube. Mengkombinasikan sebuah layanan bimbingan untuk nenanamkan perilaku Prososial dengan tayangan video tentu akan membuat siswa dapat lebih murah menangkap tujuan atau pesan yang ingin disampaikan oleh pembimbing.

Teknik layanan bimbingan yang dimaksud adalah Cinema Therapy, dimana film termasuk kedalam kategori audiovisual yang menyajikan tampilan verbal (suara/audio) dan non-verbal (gerakan/visual). Menurut Arsyad (2016) stimulus visual membuahkan hasil yang lebih baik untuk tugas-tugas seperti mengingat, mengenali, mengingat kembali, dan menghubung-hubungkan fakta dengan konsep. Bandura (dalam Corey, 2013) menyatakan bahwa belajar bisa diperoleh melalui pengalaman langsung bisa pula diperoleh secara tidak langsung dengan mengamati tingkah laku orang lain berikut konsekuensikonsekuensinya sehingga kecakapan sosial tertentu bisa diperoleh dengan mengamati dan mencontoh tingkah laku model yang ada. Brigham (dalam Dayakisni, 2015) bahwa salah satu cara untuk meningkatkan perilaku prososial ialah melalui penayangan model prilaku prososial di media.

Cinema Therapy sendiri menurut Clyman (dalam Danny, 2014) secara teknik merupakan sebuah proses atau praktik yang menginstruksikan klien untuk menonton film yang relevan dengan masalah gangguan dan disfungsi pribadi, bertujuan untuk membantu klien mengatasi berbagai isu yang bisa berdampak negatif terhadap kehidupan mereka. Wolz (2011) menyatakan bahwa Cinema Therapy dalam suasana kelompok dapat membuat anggota saling mengalami transformasi penanganan masalah satu sama lain dikarenakan mereka menyaksikan proses dengan empati.

Teknik cinema therapy dalam bimbingan kelompok dapat membantu siswa untuk saling bertukar pendapat, memahami satu sama lain, dan dapat memahami dirinya lebih jauh. Hal tersebut terjadi lewat proses diskusi para anggota kelompok tentang pesan yang terkandung dalam media film. Berbagai proses yang telah dikemukakan berbanding lurus dengan tujuan cinema therapy dalam bimbingan kelompok, yaitu untuk membantu siswa untuk mengatasi berbagai isu yang bisa berdampak negatif terhadap kehidupan mereka, termasuk didalamnya ialah siswa dapat terhindar dari rendahnya perilaku 
prososial. Terhindarnya siswa dari hal tersebut diasumsikan pula dapat membuat siswa memiliki perilaku prososial yang tinggi.

\section{METODOLOGI}

Penelitian ini akan membuat rancangan Pra-Experimental menggunakan rancangan penelitian praeksperimen One Group Pretes Postes Desaign (Sumadi Suryabrata, 2015). Populasi penelitian merupakan sejumlah subjek yang akan diteliti. Penelitian ini menggunakan populasi para siswa SMP Ihyaussalafiyah Surabaya sebanyak 1 kelas yaitu kelas VIII. Penelitian ini menggunakan sampel sebanyak 7 orang siswa yang diambil dengan menggunakan teknik purposif (purposive sampling) yaitu teknik pengambilan sampel dari populasi berdasarkan ciri-ciri yang ditentukan oleh peneliti.

Data penelitian yaitu prososial yang dikumpulkan dengan menggunakan skala pengukuran prososial siswa. Dalam angket prososial terdapat 30 soal yang mencakup 5 indikator prososial. kemudian hasilnya dianalisis dengan kolerasi butir-total. Analisis kolerasi butir-total dimaksudkan untuk menguji validitas butir dengan ketentuan suatu butir dinyatakan valid jika koefisien kolerasinya positif dan signifikan ( $\mathrm{p} 0,05$ ). Analisis korelasi butir total skala pengukuran prososial siswa menggunakan SPSS for Windows versi 23.0. Data penelitian terlebih dahulu dilakukan uji validitas isi dan uji reliabilitas belah dua spearman brown. Selanjutnya datapenelitiandianalisis dengan menggunakanteknikanalisis uji wilcoxon statistikanon-parametrik

denganbantuanprogram aplikasi SPSS forWindowsversi23.0. Untuk mengetahui benar tidaknya hipotesis yang diajukan, maka selanjutnya data tes awal dan tes akhir dengan dianalisis menggunakan statistik non parametik dengan uji Wilcoxon.Kriteria dasar pengambilan keputusannya adalah:

a. Jika Asymp. Sig $\mathrm{Z}<, 5 \%(\alpha=0,05)$ maka $\mathrm{H}_{0}$ ditolak dan $\mathrm{H}_{\mathrm{a}}$ diterima. Maka hipotesis dalam penelitian ini berbunyi: terdapat pengaruh.

b. Jika Asymp. $\operatorname{Sig} Z>5 \%(\alpha=0,05)$ maka $\mathrm{H}_{0}$ diterima dan $\mathrm{H}_{\mathrm{a}}$ ditolak. Maka hipotesis dalam penelitian ini berbunyi: tidak terdapat pengaruh.

\section{HASIL PENELITIAN}

Penelitian inidilakukan dengan caramemberikan perlakuan berupa penerapan teknik cinema therapy dalam bimbingan kelompok sebanyak 3kali kepada7 siswa kelas VIII SMP Ihyaussalafiyah Surabayayang di tetapkan sebagaisampelpenelitian, menunjukan bahwa terjadi peningkatan rerata (mean) variabel prososial (pretest) sebelum diberikan treatment sebesar 105,86 sedangkan mean variabel prososial setelah diberikan treatment teknik Cinema therapy hasil post test sebesar 114,71 .

Hal tersebut menunjukan peningkatan mean sebelum dilakukan treatment dan sesudah dilakukan treatment, dengan demikian terjadi peningkatan prososial dengan teknik Cinema therapy dalam bimbingan kelompok. Selanjutnya statistik deskriptif di uraikan pada tabel I.

Descriptive Statistics

\begin{tabular}{lccrrr}
\hline & N & Mean & $\begin{array}{c}\text { Std. } \\
\text { Deviation }\end{array}$ & $\begin{array}{c}\text { Mini } \\
\mathrm{mu}\end{array}$ & $\begin{array}{c}\text { Maxim } \\
\text { um }\end{array}$ \\
\hline $\begin{array}{l}\text { Pret } \\
\text { est }\end{array}$ & 7 & 105,86 & 1,069 & 104 & 107 \\
$\begin{array}{l}\text { Postt } \\
\text { est }\end{array}$ & 7 & 114,71 & 1,380 & 113 & 117 \\
\hline
\end{tabular}

Tabel I. Statistik Deskriptif Pre-Test dan

Post-Test Prososial Siswa KelasVIII SMP Ihyaussalafiyah Surabaya

Hipotesis dalampenelitian ini adalah terdapatpengaruhyang signifikan penggunaan teknik cinema therapy dalam bimbingan kelompok terhadap perilaku prososial siswa.

Berdasarkan hasil perhitungan diperoleh Asymp. Sig = 0,017 Perbandingan Asymp. Sig $=0,017<\alpha=0,05$ maka $\mathrm{H}_{0}$ ditolak dan $\mathrm{H}_{\mathrm{a}}$ diterima. Artinya adalah terdapat pengaruh yang signifikan pada penggunaan teknik cinema therapy dalam bimbingan kelompok terhadap perilaku prososial siswa. Tabel II menunujukan Uji Wilcoxon.

Test Statistics ${ }^{\mathrm{a}}$

\begin{tabular}{lr}
\hline & Posttest - Pretest \\
\hline $\mathrm{Z}$ & $-2.384^{\mathrm{b}}$
\end{tabular}

Asymp. Sig. (2tailed)

a. Wilcoxon Signed Ranks Test

b. Based on negative ranks.

Tabel II. Hasil Uji Wilcoxon Prososial 
Jurnal HELPER, Vol 35 No 2 (2018) 22 - 25

Bimbingan dan Konseling Universitas PGRI Adi Buana Surabaya

ISSN: 02162938

\section{KESIMPULAN}

Berdasarkan hasilpenelitian yang telah diuraikandi atas,dapat disimpulkan bahwaterdapat pengaruh positifyang signifikan penggunaan teknik cinema therapydalam bimbingan kelompok terhadap perilaku prososial siswa kelas VIII SMP Ihyaussalafiyah.

\section{DAFTAR PUSTAKA}

Arsyad, Azhar. (2016). Media Pembelajaran. Jakarta: Raja Grafindo Persada.

Baron, A. Robert, Nyla R. Branscombe. (2012). Social Psychology. New Jersey: Pearson Education, Inc.

Corey, Gerald. (2013). Teori dan Praktek Konseling dan Psikoterapi. Bandung: PT Refika Aditama.

Danny, W. Pettry. (2014). Cinema Therapy an Idea for Recreational Therapist. Huntington: www.DannyPettry.com.

Isnandar, T. W. (2010). Hubungan antara Konsep Diri dengan Perilaku Prososial pada SMA 1 Purworejo. Skripsi Psikologi UniversitasMuhammadiyah Surakarta.

Niva, Haeruddin. (2016). Penerapan Pendekatan Cinema Therapy untuk Meningkatkan Perilaku Prososial pada Siswa Bosowa International School Makassar. Jurnal Universitas Negeri Makssar.

Nursalim, Mochamad. (2015). Pengembangan Media Bimbingan dan Konseling. Jakarta: PT. Indeks.

Sumadi Suryabrata. (2015). Metodologi Penelitian. Jakarta: PT Bumi Aksara.

Syamsu Yusuf. (2014). Psikologi Perkembangan Anak \& Remaja. Bandung: Rosda.

Tri Dayakisni, Hudaniah. (2015). Psikologi Sosial. Malang: UMM Press.

Wolz, Birgit. (2011). Cinema Therapy: Using the Power of Imagery in Films for the Therapeutic Process. Tersedia di http://www.shamonjgifts.com/wpcontent/uploads/2011/11/Cinema
Therapy.pdf, diakses pada tanggal 23

Agustus 2017) 